\title{
Molecular Mechanisms Underlying Behaviors Related to Nicotine Addiction
}

\author{
Marina R. Picciotto ${ }^{1}$ and Paul J. Kenny ${ }^{2}$ \\ ${ }^{1}$ Department of Psychiatry, Yale University School of Medicine, New Haven, Connecticut 06508 \\ ${ }^{2}$ Department of Molecular Therapeutics, The Scripps Research Institute, Florida Campus, Jupiter, Florida 33458 \\ Correspondence: marina.picciotto@yale.edu
}

\begin{abstract}
Tobacco smoking results in more than 5 million deaths each year and accounts for almost $90 \%$ of all deaths from lung cancer. Nicotine, the major reinforcing component of tobacco smoke, acts in the brain through the neuronal nicotinic acetylcholine receptors (nAChRs). The $n A C h R s$ are allosterically regulated, ligand-gated ion channels consisting of five membrane-spanning subunits. Twelve mammalian $\alpha$ subunits $(\alpha 2-\alpha 10)$ and $\beta$ subunits ( $\beta 2-\beta 4)$ have been cloned. The predominant nAChR subtypes in mammalian brain are those containing $\alpha 4$ and $\beta 2$ subunits (denoted as $\alpha 4 \beta 2^{*}$ nAChRs). The $\alpha 4 \beta 2^{*}$ nAChRs mediate many behaviors related to nicotine addiction and are the primary targets for currently approved smoking cessation agents. Considering the large number of nAChR subunits in the brain, it is likely that nAChRs containing subunits in addition to $\alpha 4$ and $\beta 2$ also play a role in tobacco smoking. Indeed, genetic variation in the CHRNA5-CHRNA3-CHRNB4 gene cluster, encoding the $\alpha 5, \alpha 3$, and $\beta 4 \mathrm{nAChR}$ subunits, respectively, has been shown to increase vulnerability to tobacco dependence and smoking-associated diseases including lung cancer. Moreover, mice in which expression of $\alpha 5$ or $\beta 4$ subunits has been genetically modified have profoundly altered patterns of nicotine consumption. In addition to the reinforcing properties of nicotine, the effects of nicotine on appetite, attention, and mood are also thought to contribute to establishment and maintenance of the tobacco smoking habit. Here we review recent insights into the behavioral actions of nicotine and the nAChRs subtypes involved, which likely contribute to the development of tobacco dependence in smokers.
\end{abstract}

\section{NICOTINIC RECEPTOR SUBTYPES INVOLVED IN CONTROL OF THE MESOLIMBIC SYSTEM AND NICOTINE REINFORCEMENT}

The mesolimbic dopamine (DA) system is a central mediator of drug reward and reinforcement (Koob 1992). Lesions of the ventral tegmental area (VTA) and its primary projection area, the nucleus accumbens (nAc), greatly attenuate nicotine self-administration and the psychostimulant properties of nicotine (its ability to increase locomotion [Clarke et al. 1988; Corrigall et al. 1992, 1994]). A great deal of progress has been made in identifying the $\mathrm{nAChR}$ subtypes expressed in both the dopaminergic and GABAergic neurons of the VTA and on neuronal terminals in the nAc (Klink et al. 2001; Zoli et al. 2002). DA neurons express

Editors: R. Christopher Pierce and Paul J. Kenny

Additional Perspectives on Addiction available at www.perspectivesinmedicine.org

Copyright (C) 2013 Cold Spring Harbor Laboratory Press; all rights reserved; doi: 10.1101/cshperspect.a012112

Cite this article as Cold Spring Harb Perspect Med 2013;3:a012112 
M.R. Picciotto and P.J. Kenny

heteromeric nAChRs containing the $\alpha 4, \alpha 5, \alpha 6$, $\beta 2$, and $\beta 3$ subunits in various combinations, with the predominant subtypes being $\alpha 4 / \beta 2 /$ $\alpha 5$ and $\alpha 4 / \alpha 6 / \beta 2 / \beta 3$. The $\alpha 6$ subunit appears to be selectively expressed in DA neurons (Le Novère et al. 1996; Drenan et al. 2008b), although a recent report has suggested that there may be an effect of $\alpha 6$-containing receptors on GABA transmission in the VTA (Yang et al. 2011). In addition, $\alpha 7$ homomeric nAChRs are expressed in DA neurons (Klink et al. 2001), as well as on neuronal terminals on afferents to the VTA (Mansvelder et al. 2002; Wooltorton et al. 2003).

Electrophysiological studies have shown that $\mathrm{nAChRs}$ containing the $\beta 2$ subunit are essential for the ability of nicotine to depolarize DA cell bodies in the VTA and to increase their firing rate (Picciotto et al. 1998; Zhou et al. 2001). While the predominant inward currents owing to nicotine in these neurons involve $\beta 2^{*}$ nAChRs, nicotine can also modulate the presynaptic input to DA neurons from GABAergic and glutamatergic terminals impinging on them. In a slice preparation, nicotine can potentiate glutamate input to DA neurons through $\alpha 7 \mathrm{nAChRs}$, resulting in long-term potentiation of those inputs (Mansvelder and McGehee $2000)$. In addition, nicotine can desensitize $\beta 2^{*}$ nAChRs on GABAergic inputs to DA neurons, resulting in a shift from mixed excitation and inhibition of DA neurons by nicotine, to a more unmixed stimulation of nAChRs on presynaptic glutamatergic terminals (Mansvelder et al. 2002; Wooltorton et al. 2003).

Evidence from mouse genetic models with knockout or mutations of $\mathrm{nAChR}$ subunits suggests that the postsynaptic depolarization of DA neurons is essential for behaviors related to nicotine reward and reinforcement such as nicotine place preference and self-administration. Knockout of the $\beta 2$ subunit abolishes nicotinemediated DA release (Picciotto et al. 1998; Grady et al. 2001), nicotine-induced locomotor activation (King et al. 2004), nicotine self-administration (Picciotto et al. 1998; Maskos et al. 2005), and nicotine place preference (Walters et al. 2006; Brunzell et al. 2009; Mineur et al. 2009a). Similarly, knockout of the $\alpha 4$ subunit abolishes intracerebroventricular (i.c.v.) selfadministration of nicotine, consistent with evidence that $\alpha 4 / \beta 2 * \mathrm{nAChRs}$ are required for depolarization of DA neurons in the VTA (Exley et al. 2011; McGranahan et al. 2011). Conversely, knockin of a hypersensitive $\alpha 4$ subunit shifts the dose-response curve for nicotine-induced increases in DA neuron firing to the left, and results in nicotine place preference at very low doses of the drug (Tapper et al. 2004). Similarly, expression of a hypersensitive $\alpha 6$ subunit in a bacterial artificial chromosome (BAC) transgenic mouse line potentiates nicotine-induced burst firing in DA neurons, and potentiates nicotine place preference at low doses of nicotine (Drenan et al. 2008a, 2010).

A series of recent studies have provided further support for the involvement of $\alpha 6^{*}$ $\mathrm{nAChRs}$ in nicotine self-administration. Mice lacking the $\alpha 6$ subunit do not acquire intravenous nicotine self-administration (Pons et al. 2008). Similarly, conotoxins selective for $\alpha 6 /$ $\beta 2^{*}$ nAChRs disrupt nicotine self-administration in the rat when infused into the VTA (Gotti et al. 2010) and following self-administration training, these conotoxins decrease the motivation to lever press for nicotine on a progressive ratio schedule (Brunzell et al. 2010). In contrast, mice with constitutive knockout of the $\alpha 6$ subunit, intra-VTA self-administration of nicotine is not disrupted, whereas $\alpha 4^{*} \mathrm{nAChRs}$ are necessary and sufficient for both intra-VTA selfadministration, as well as nicotine-induced increases in firing of DA neurons (Exley et al. 2011; McGranahan et al. 2011); however, $\alpha 4$ and $\alpha 6$ subunits are both required for the ability of nicotine to gate DA transmission in the $\mathrm{nAc}$, suggesting that $\mathrm{nAChRs}$ in $\mathrm{nAc}$ may be more important in motivation to self-administer nicotine (Brunzell et al. 2010; Exley et al. 2011) and that this may affect acquisition of intravenous self-administration behavior (Pons et al. 2008; Gotti et al. 2010), as well as nicotine-dependent locomotor activation (Gotti et al. 2010).

Despite its contribution to nicotine-dependent plasticity in the VTA, knockout of the $\alpha 7$ subunit in mice does not affect nicotine place preference (Walters et al. 2006) or acquisition of nicotine self-administration (Pons et al. 2008); 
however, antagonizing $\alpha 7$-type nAChRs in the $\mathrm{nAc}$ or anterior cingulate cortex in the rat increases the motivation to self-administer nicotine, whereas infusion of a selective $\alpha 7$ agonist decreases motivation, as measured using a progressive ratio schedule (Brunzell and McIntosh 2012). $\alpha 7$-type nAChRs may modulate, rather than mediate, nicotine reinforcement and therefore the effect of $\alpha 7$ knockout may be more subtle than knockout of $\beta 2^{*}$ nAChRs.

An important role for $\mathrm{nAChRs}$ in the VTA in nicotine reinforcement has been shown using both molecular genetic and pharmacological techniques. Selective viral reexpression of $\beta 2^{*}$ (Maskos et al. 2005; Pons et al. 2008) or $\alpha 4^{*}$ nAChRs in the VTA is sufficient to support both intra-VTA (Maskos et al. 2005) and systemic nicotine self-administration (Pons et al. 2008), identifying the nAChR subtypes necessary for nicotine reinforcement, as well as demonstrating the importance of nAChRs within the VTA itself for this behavior. This is consistent with previous studies suggesting that $\mathrm{nAChRs}$ within the VTA are critical for nicotine reward, because local infusion of a nicotinic agonist into the VTA, but not the nAc, is sufficient for nicotine place preference in the rat (Museo and Wise 1994).

Thus, molecular genetic studies support the idea that $\alpha 4 / \alpha 6 / \beta 2 *$ nAChRs on DA neurons in the VTA are essential for nicotine reinforcement. These experiments in mice are supported by pharmacological studies in rats, and provide a consistent molecular subtype and neuroanatomical locus for the rewarding and reinforcing effects of nicotine.

\section{NICOTINIC RECEPTORS AND CIRCUITS INVOLVED IN AVERSION AND NICOTINE WITHDRAWAL: FOCUS ON THE HABENULA- INTERPEDUNCULAR PATHWAY}

The habenula is a diencephalic structure located on the dorsomedial surface of the caudal thalamus that is segregated into medial $(\mathrm{MHb})$ and lateral $(\mathrm{LHb})$ domains (Lecourtier and Kelly 2007; Hikosaka 2010). The MHb and $\mathrm{LHb}$ are anatomically, chemically, and functionally distinct subnuclei, each with different com- plements of afferent and efferent connections. $\mathrm{LHb}$ receives afferent inputs from, and projects extensively to, midbrain and hindbrain sites. In particular, the LHb projects densely to the rostromedial tegmental nucleus (RMTg) (Jhou et al. 2009), and has a well-established inhibitory effect on the firing of midbrain dopamine neurons (Lecourtier and Kelly 2007; Matsumoto and Hikosaka 2009; Hikosaka 2010; Bromberg-Martin and Hikosaka 2011). LHb neurons are excited by omission of anticipated rewards or exposure to aversive stimuli (Lecourtier and Kelly 2007; Matsumoto and Hikosaka 2009; Hikosaka 2010; Bromberg-Martin and Hikosaka 2011). This has prompted considerable interest in the role for LHb neurons in encoding negative motivational states. Unlike the $\mathrm{LHb}$, the $\mathrm{MHb}$ projects almost exclusively to the interpeduncular nucleus (IPN) via the fasciculus retroflexus (Fr) (Lecourtier and Kelly 2007; Hikosaka 2010). MHb is comprised of neurons that produce the neurotransmitters acetylcholine or substance P (Cuello et al. 1978; Eckenrode et al. 1987), and a small population that produce the cytokine interleukin-18 (IL18) (Sugama et al. 2002). However, it is believed that most $\mathrm{MHb}$ neurons also produce and corelease glutamate, with this excitatory neurotransmitter considered the major functional transmitter at the MHb-IPN synapse (Mata et al. 1977; Vincent et al. 1980; Girod et al. 2000; Ren et al. 2011). The MHb contains some of the highest densities of nicotine-binding sites in brain (Mugnaini et al. 2002). In particular, the highest density of $\alpha 5, \alpha 3$, and $\beta 4$ $\mathrm{nAChR}$ subunit expression in brain is detected in $\mathrm{MHb}$ and/or IPN (De Biasi and Salas 2008). Indeed, approximately $90 \%-100 \%$ of $\mathrm{MHb}$ neurons express $\alpha 3, \alpha 4, \alpha 5, \beta 2$, and $\beta 4$ nAChR subunits (Sheffield et al. 2000), and in mouse brain slices through the $\mathrm{MHb},>85 \%$ of neurons respond to nicotine with an inward current, and these currents are not altered in mice lacking the $\beta 2 \mathrm{nAChR}$ subunit (Picciotto et al. 1995). It is also hypothesized that $\sim 20 \%$ of functional $\mathrm{nAChRs}$ in rat $\mathrm{MHb}$ neurons that project to IPN contain $\alpha 5$ subunits (Grady et al. 2009).

The fact that the MHb-IPN pathway is enriched in $\alpha 5, \alpha 3$, and $\beta 4 \mathrm{nAChR}$ subunits is of 
particular interest in the context of recent human genetics findings. It has been shown that allelic variation in the $\alpha 5 / \alpha 3 / \beta 4 \mathrm{nAChR}$ subunit gene cluster located in chromosome region 15 q25 significantly increases the risk of tobacco addiction (Saccone et al. 2007; Berrettini et al. 2008; Lips et al. 2010). For example, a single nucleotide polymorphism (SNP) in CHRNA5 (rs16969968) that is very common in those of European descent (minor allele frequency $=$ 0.42 ) increases the risk of tobacco dependence by $\sim 30 \%$ in individuals carrying a single copy of the variant, and more than doubles the risk in those carrying two risk alleles (Bierut et al. 2008; Wang et al. 2009); a finding that has been consistently replicated (Berrettini et al. 2008; Bierut et al. 2008; Grucza et al. 2008; Stevens et al. 2008). The rs 16969968 risk variant is associated with heavy smoking (Berrettini et al. 2008; Bierut et al. 2008; Grucza et al. 2008; Stevens et al. 2008), early onset of smoking behavior (Weiss et al. 2008), and with "pleasurable buzz" from tobacco (Sherva et al. 2008). In addition, the same genetic variability in CHRNA5 is also a major risk factor for lung cancer and chronic obstructive pulmonary disease (COPD) in smokers (Amos et al. 2008; Hung et al. 2008; Wang et al. 2010), likely reflecting higher levels of tobacco dependence in individuals carrying risk alleles and consequently greater exposure to carcinogens and toxins contained in tobacco smoke (Le Marchand et al. 2008; Thorgeirsson et al. 2008). In addition to the rs 16969968 SNP in CHRNA5, there is also increased risk of tobacco dependence in individuals carrying the rs6495308, rs578776, or rs1051730 SNPs in CHRNA3 (Berrettini et al. 2008; Saccone et al. 2009), and rs1948 in CHRNB4 (Schlaepfer et al. 2008).

The above findings suggest that nAChRs containing $\alpha 5, \alpha 3$, and/or $\beta 4 \mathrm{nAChR}$ subunits, densely expressed in the MHb-IPN pathway, regulate addiction-related actions of nicotine. Consistent with an important role for $\alpha 5^{*}$ nAChRs in regulating nicotine intake, it was recently shown that mice with a null mutation for this subunit intravenously self-administered far more nicotine than their wild-type littermates (Fowler et al. 2011). Interestingly, the knockout mice consumed more nicotine only when higher unit doses of the drug were available (Fowler et al. 2011). By using Fos immunoreactivity as a measure of neuronal activation, it was shown that the MHb-IPN pathway of the knockout mice was far less sensitive to nicotine-induced activation than wild-type mice (Fowler et al. 2011). Moreover, chemical inactivation of the $\mathrm{MHb}$ or the IPN using the local anesthetic lidocaine, or disruption of NMDA receptor-mediated glutamatergic transmission in these sites using the competitive antagonist LY2358959, increased nicotine selfadministration behavior in rats in a manner similar to what was observed in $\alpha 5 \mathrm{nAChR}$ subunit knockout mice (Fowler et al. 2011). Virusmediated reexpression of the $\alpha 5 \mathrm{nAChR}$ subunit in the MHb-IPN pathway of knockout mice abolished the increased nicotine intake seen at higher doses of nicotine (Fowler et al. 2011). Conversely, RNA interference-mediated knockdown of $\alpha 5 \mathrm{nAChR}$ subunits in the MHb-IPN pathway in rats resulted in increased nicotine intake at higher unit doses of the drug, very similar to the same behavioral profile detected in the knockout mice (Fowler et al. 2011). Finally, knockdown of $\alpha 5 \mathrm{nAChR}$ subunits in the MHb-IPN pathway in rats decreased their sensitivity to the reward-inhibiting (i.e., aversive) actions of higher nicotine doses compared with control rats, as measured by nicotine-induced elevations of intracranial self-stimulation (ICSS) reward thresholds (Fowler et al. 2011). Taken together, these findings suggest that nicotine activates the MHb-IPN pathway through stimulatory effects on $\alpha 5^{*}$ nAChRs. Nicotineinduced activation of the MHb-IPN pathway results in a negative motivational signal that serves to limit further nicotine intake. Hence, disruption of $\alpha 5^{*} \mathrm{nAChR}$ signaling diminishes the stimulatory effects of nicotine on MHb-IPN activity, and thereby permits consumption of greater quantities of nicotine.

In addition to $\alpha 5^{*} \mathrm{nAChRs,} \mathrm{evidence} \mathrm{sug-}$ gests that $\beta 4^{*} \mathrm{nAChRs}$ in the MHb-IPN pathway also play an important role in regulating nicotine consumption. Specifically, overexpression of $\beta 4^{*}$ nAChRs in mice using BAC transgenic technology resulted in greatly diminished 
sensitivity to the reinforcing properties of orally consumed nicotine solutions and far less consumption of the drug than wild-type mice (Frahm et al. 2011). This finding suggests that, similar to $\alpha 5^{*}$ nAChRs, $\beta 4^{*}$ nAChRs in the $\mathrm{MHb}-\mathrm{IPN}$ pathway also regulate sensitivity to the aversive effects of nicotine that control the quantities of the drug consumed.

Dependence on tobacco smoking depends not only on the balance between the rewarding and aversive action of nicotine described above, but also on escape from the aversive consequences of nicotine withdrawal (Doherty et al. 1995; Kenny and Markou 2001). Indeed, withdrawal duration and severity predicts relapse in abstinent human smokers (Piasecki et al. 1998, $2000,2003)$. The nicotine withdrawal syndrome in abstinent smokers is composed of "physical" or somatic components, and "affective" components. The most common somatic symptoms include bradycardia, gastrointestinal discomfort, and increased appetite. Affective symptoms primarily include depressed mood including anhedonia, dysphoria, anxiety, irritability, difficulty concentrating, and craving (Parrott 1993; Doherty et al. 1995; Kenny and Markou 2001). Similar to $\alpha 5$ subunits, $\alpha 2$ subunits are highly enriched in the IPN (Grady et al. 2009). Recently, it was shown that $\alpha 5$ and $\alpha 2$ subunit knockout mice that were dependent on nicotine (delivered through subcutaneously implanted osmotic minipumps) did not show somatic signs of nicotine withdrawal when withdrawal was precipitated with the $\mathrm{nAChR}$ antagonist mecamylamine (Salas et al. 2009). Moreover, direct infusion of mecamylamine into the IPN, but not the VTA, of nicotine-dependent wild-type mice precipitated the expression of somatic withdrawal signs (Salas et al. 2009). This suggests that $\alpha 5^{*}$ and $\alpha 2^{*} \mathrm{nAChRs}$ in the MHbIPN pathway, and perhaps other nAChR subtypes enriched in this pathway, regulate the expression of somatic signs of nicotine withdrawal. However, little is known concerning the role for nAChRs in the MHb-IPN tract in regulating affective aspects of nicotine withdrawal, and in particular, withdrawal-associated reward deficits that may motivate relapse during periods of abstinence in human smokers.
Taken together, the above findings support a key role for $\alpha 5$ and $\beta 4$, and perhaps also $\alpha 2$ and $\alpha 3$ nAChRs, which are enriched in the $\mathrm{MHb}-\mathrm{IPN}$ pathway in regulating nicotine reinforcement and the expression of the nicotine withdrawal syndrome in nicotine-dependent rodents. As such, nAChRs containing these subunits may be important targets for the development of novel therapeutics for smoking cessation.

\section{NICOTINIC INVOLVEMENT IN BEHAVIORS RELATED TO \\ ONGOING SMOKING: EFFECTS OF NICOTINE ON DEPRESSION, APPETITE, AND ATTENTION}

Nicotine reinforcement and avoidance of the aversive effects of nicotine withdrawal are clearly fundamental for ongoing smoking, but a number of other factors are also likely to contribute to smoking behavior in humans. nAChRs are expressed throughout the brain on both excitatory and inhibitory neurons, with the ability to increase inhibition of circuits when excitation is high and to increase excitation when circuits are less active (Picciotto 2003). The result of this circuit-level integration is that nicotine can modulate behavioral function bidirectionally, acting as a stimulant and increasing anxiety under some conditions and decreasing activity and anxiety in others (Picciotto 2003).

Some individuals report that they smoke to improve attention (Rusted and Warburton 1992; Warburton et al. 1992), and the ability of smoking to improve attentional function in individuals with schizophrenia (George et al. 2002) is likely to contribute to their extremely high rates of smoking. Similarly, a large proportion of smokers report that they smoke to control symptoms of anxiety and depression (Picciotto et al. 2002), and the rate of smoking in individuals with affective disorders is more than double the rate in the general population (Kalman et al. 2005). The idea that some individuals smoke to self-medicate psychiatric symptoms is thought to underlie the high rate of smoking in individuals with psychiatric illness, and some estimates suggest that $\sim 44 \%$ of cigarettes are 
M.R. Picciotto and P.J. Kenny

sold to individuals with a current psychiatric condition (Lasser et al. 2000).

Effects of nAChRs on Anxiety- and Depression-Like Behaviors

Studies in mouse genetic models have helped identify the nAChR subtypes involved in a number of behavioral effects of nicotine that may affect human smoking. Nicotine is known to have both anxiolytic and anxiogenic effects in rodents (File et al. 2000), and these effects are likely to depend on different nAChR subtypes. For example, chronic administration of nicotine increased anxiety-like behavior in female, but not male, mice (Caldarone et al. 2008), whereas knockout mice lacking the $\beta 4$ subunit show less anxiety-like behaviors at baseline (Salas et al. 2003) and no difference in anxiety-like behaviors were seen at baseline or following nicotine administration in mice lacking the $\beta 2$ subunit (Caldarone et al. 2008). Similarly, female, but not male, knockout mice lacking the $\alpha 5$ subunit showed reduced anxiety-like behavior, and this may be related to progesterone effects on $\alpha 5$ subunit expression (Gangitano et al. 2009). These data suggest that stimulation of $\alpha 5 \beta 4^{*}$ $\mathrm{nAChRs}$ is important for the anxiogenic effects of nicotine.

The effects of nicotine on depression-like behavior are also complex. Studies in the Flinders sensitive line of rats have shown that acute nicotine administration is antidepressant-like in the forced swim test and that this effect can be blocked by the nicotinic antagonist mecamylamine, suggesting that activation of $\mathrm{nAChRs}$ decreases depression-like behavior in this model (Tizabi et al. 2000). In contrast, the nicotinic antagonist mecamylamine has antidepressantlike effects in mice (Caldarone et al. 2004; Rabenstein et al. 2006; Andreasen et al. 2009), and can be effective as an add-on medication in depressed human subjects who are nonresponsive to an SSRI (George et al. 2008). Similarly, nicotinic partial agonists, that would be expected to decrease activity of acetylcholine at endogenous nAChRs when cholinergic tone is high but increase activity of nAChRs when cholinergic tone is low, are effective in mouse models of antidepressant efficacy (Mineur et al. 2007, 2009b, 2011b; Rollema et al. 2009; Caldarone et al. 2011) and in human smokers (Philip et al. 2009). These data suggest that inhibition of nAChRs in some neuronal subtypes or brain areas and activation in others may contribute to an antidepressant-like effect of nicotinic drugs, so the cycles of nAChR activation and desensitization experienced by smokers may result in fluctuations in depressive symptoms throughout the day. Both the antagonist mecamylamine (Rabenstein et al. 2006) and the partial agonist sazetidine (Caldarone et al. 2011), as well as the classical antidepressant amitriptyline (Caldarone et al. 2004), are ineffective in mice lacking the $\beta 2$ subunit, and these knockout mice show decreased depression-like behavior at baseline, suggesting that $\beta 2^{*} \mathrm{nAChRs}$ are critical for the antidepressant-like effects of nicotinic drugs; however, mice lacking the $\alpha 7$ subunit are also resistant to the antidepressant-like effects of mecamylamine (Rabenstein et al. 2006), and the effects of the partial agonist sazetidine could be blocked with mecamylamine (Caldarone et al. 2011), suggesting that other nAChR subtypes may also contribute to the antidepressantlike effects of nicotinic drugs, and that activation as well as inhibition of nAChRs can result in antidepressant-like effects.

\section{Effects of nAChRs on Behaviors Related to Attention}

In addition to effects on anxiety and depression, nicotine and nicotinic drugs can improve attention in control subjects (Rusted and Warburton 1992) and individuals with schizophrenia (Sacco et al. 2004). Interestingly, after control subjects quit smoking and transition past the acute withdrawal period, their working memory function improves compared with when they were smoking (George et al. 2002). In contrast, individuals with schizophrenia show impaired attentional performance once they quit smoking (George et al. 2002). Genetic and functional studies have implicated $\alpha 7 \mathrm{nAChRs}$ in prepulse inhibition, a physiological marker associated with schizophrenia (Leonard et al. 2000; Freedman et al. 2003). Mice lacking the $\alpha 7$ subunit 
have been shown to have impaired trace eyeblink conditioning (Brown et al. 2010). These data suggest that optimal $\mathrm{nAChR}$ stimulation is achieved at baseline in control subjects or wild-type mice with normal $\alpha 7 \mathrm{nAChR}$ levels, whereas nicotine from tobacco smoke can further improve attention in individuals with schizophrenia.

Studies using knockout mice with lentiviral-mediated reexpression have shown that $\beta 2{ }^{*} \mathrm{nAChRs}$ in the prelimbic medial prefrontal cortex (mPFC) are important for normal performance of the five-choice serial reaction time task measuring visual attention. Similarly, rapid acetylcholine transients in the $\mathrm{mPFC}$ are correlated with attention to brief cues, and mice lacking the $\beta 2$, but not the $\alpha 7$, subunit show impaired performance in an attentional task (Parikh et al. 2007, 2008). Studies in rodents have also implicated nAChRs on glutamatergic thalamocortical neurons impinging on layer five pyramidal neurons in the prefrontal cortex as an important site for nAChR control of attention (Lambe et al. 2005; Bailey et al. 2010). Overall, it appears that nAChRs in thalamo-corticothalamic loops are important for regulating glutamate release in this circuit, and for mediating the effects of acetylcholine on attentional function (Heath and Picciotto 2009).

In addition to effects of nicotine on attentional function in adulthood, many studies have shown a role for nAChRs in maturation of circuits important for attention during development (reviewed in Heath and Picciotto 2009). Mice administered nicotine during the adolescent period show deficits in the five-choice serial reaction time task that are associated with decreased expression of mGluR2 receptors, and that are rescued by administration of mGluR2 agonists (Counotte et al. 2011). Similarly, $\alpha 5 /$ $\beta 2 *$ nAChRs on layer six cortical glutamatergic projection neurons to the thalamus are essential in maturation of this circuit and for normal adult performance in passive avoidance, a somatosensory aversive learning task (King et al. 2003; Heath et al. 2010). Electrophysiological studies have shown that currents mediated through $\alpha 5 / \beta 2^{*}$ nAChRs are maximal in the early postnatal period (Kassam et al. 2008). Nic- otine administration during this same period alters performance in the passive avoidance task in normal mice as well as in mice with expression of $\beta 2 *$ nAChRs exclusively in corticothalamic neurons (Heath et al. 2010), suggesting that disrupting normal acetylcholine signaling through these $\mathrm{nAChRs}$ during a critical period has lasting effects on function of the corticothalamic circuit in passive avoidance behavior. Interestingly, modulation of nicotinic function through the lynxl protein is also important for regulating the critical period for activity-dependent visual system development (Morishita et al. 2010).

\section{Effects of nAChRs on Food Intake}

The anorexic effects of smoking have been welldocumented in human subjects, and the principal reason cited by female teenagers for why they smoke is weight control (Voorhees et al. 2002). On average, smokers weigh $\sim 5 \mathrm{~kg}$ less than nonsmokers and have significantly lower body mass index than nonsmokers (Albanes et al. 1987). Similarly, nicotine decreases feeding in animal models (Grunberg et al. 1987), suggesting that the nicotine in tobacco is important for the effects of smoking on appetite. Whereas $\beta 2 \alpha 4 \alpha 6^{*} \mathrm{nAChRs}$ are critical for nicotine reward and reinforcement, $\beta 4^{*} \mathrm{nAChRs}$ on proopiomelanocortin (POMC) neurons in the arcuate nucleus of the hypothalamus are necessary for the appetite-suppressing effects of nicotine (Mineur et al. 2011a). There are a number of $\mathrm{nAChR}$ subtypes expressed in the hypothalamus (Jo et al. 2002, 2005), and nicotine can stimulate the firing of both POMC neurons, which signal satiety, and neuropeptide Y (NPY) neurons, which stimulate food seeking (Huang et al. 2011). Interestingly, in a slice preparation, the effects of nicotine on firing of POMC neurons persist longer than firing of NPY neurons, showing that at the circuit level, stimulation of nAChRs shifts the balance toward neuronal patterns that signal satiety (Huang et al. 2011).

Although $\beta 4^{*}$ nAChRs on POMC neurons can signal satiety, nAChRs in the mesolimbic dopamine system may be more important for the motivation to work for food. The DA system 
is important for the hedonic value of both drugs of abuse, like nicotine, and palatable foods (Kenny 2011). Food or sugar intake can increase acetylcholine release in the VTA (Hajnal et al. 1998; Rada et al. 2000), and withdrawal from binge eating increases acetylcholine release in the nAc (Avena et al. 2008). Interestingly, blocking $\alpha 7$ nicotinic AChRs in the VTA can decrease food seeking (Schilstrom et al. 1998). In contrast, previous nicotine exposure increases the motivation of mice to work for food, and this is attributable to non- $\beta 2^{*}$ nAChRs (Brunzell et al. 2006). Taken together, these data show that, in addition to its effects on satiety mediated through POMC neuron signaling, acetylcholine in the mesolimbic system is also likely to affect motivation to seek palatable foods and to modulate their hedonic value through distinct nAChR subtypes.

\section{CONCLUSIONS}

The high-affinity $\alpha 4 \beta 2^{*}$ nAChRs play a key role in the behavioral actions of nicotine that contribute to the development of tobacco dependence, including its effects on brain circuitries involved in reinforcement, mood, attention, and food consumption. Recent evidence has shed important light on other nAChR subunits that may also be incorporated into the $\alpha 4 \beta 2^{*}$ nAChRs that regulate these processes. For example, incorporation of $\alpha 6$ and $\beta 3 \mathrm{nAChR}$ subunits in $\alpha 4 \beta 2^{*}$ nAChRs in the mesoaccumbens pathway gives rise to a $\mathrm{nAChR}$ subtype $\left(\alpha 4 \alpha 6 \beta 2 \beta 3^{*}\right)$ that appears to play a particularly important role in nicotine reinforcement. In addition, nAChR subtypes containing $\alpha 5, \alpha 3$, and/or $\beta 4 \mathrm{nAChR}$ subunits have been implicated in regulating the aversive properties of nicotine that control the quantities of the drug consumed and in the development of tobacco dependence. In addition, $\beta 4^{*}$ nAChRs also play an important role in appetite regulation, particularly the inhibitory effects of nicotine on appetite that underlie the anorectic effects of tobacco smoke. A more refined understanding of the precise contribution of discrete $\mathrm{nAChR}$ subtypes to these addiction-relevant properties of nicotine may reveal important new targets for the development of novel therapeutics for tobacco dependence. Moreover, such novel therapeutics could also have utility for the treatment of mood and attention disorders and the control of body weight.

\section{ACKNOWLEDGMENTS}

The authors are supported by grants DA14241 (M.R.P.) and DA020686 (P.J.K.) from the National Institute on Drug Abuse.

\section{REFERENCES}

Albanes D, Jones DY, Micozzi MS, Mattson ME. 1987. Associations between smoking and body weight in the US population: Analysis of NHANES II. Am J Pub Health 77: $439-444$.

Amos CI, Wu X, Broderick P, Gorlov IP, Gu J, Eisen T, Dong Q, Zhang Q, Gu X, Vijayakrishnan J, et al. 2008. Genomewide association scan of tag SNPs identifies a susceptibility locus for lung cancer at 15q25.1. Nature Gen 40: 616-622.

Andreasen JT, Olsen GM, Wiborg O, Redrobe JP. 2009. Antidepressant-like effects of nicotinic acetylcholine receptor antagonists, but not agonists, in the mouse forced swim and mouse tail suspension tests. J Psychopharmacology 23: 797-804.

Avena NM, Bocarsly ME, Rada P, Kim A, Hoebel BG. 2008. After daily bingeing on a sucrose solution, food deprivation induces anxiety and accumbens dopamine/acetylcholine imbalance. Physiol Behav 94: 309-315.

Bailey CDC, De Biasi M, Fletcher PJ, Lambe EK. 2010. The nicotinic acetylcholine receptor $\alpha 5$ subunit plays a key role in attention circuitry and accuracy. J Neurosci 30: 9241-9252.

Berrettini W, Yuan X, Tozzi F, Song K, Francks C, Chilcoat H, Waterworth D, Muglia P, Mooser V. 2008. $\alpha-5 / \alpha-3$ Nicotinic receptor subunit alleles increase risk for heavy smoking. Mol Psychiatry 13: 368-373.

Bierut LJ, Stitzel JA, Wang JC, Hinrichs AL, Grucza RA, Xuei X, Saccone NL, Saccone SF, Bertelsen S, Fox L, et al. 2008 Variants in nicotinic receptors and risk for nicotine dependence. Am J Psychiatry 165: 1163-1171.

Bromberg-Martin ES, Hikosaka O. 2011. Lateral habenula neurons signal errors in the prediction of reward information. Nat Neurosci 14: 1209-1216.

Brown K, Comalli D, De Biasi M, Woodruff-Pak D. 2010. Trace eyeblink conditioning is impaired in $\alpha 7$ but not in $\beta 2$ nicotinic acetylcholine receptor knockout mice. Front Behav Neurosci 4: 166.

Brunzell D, McIntosh J. 2012. $\alpha 7$ Nicotinic acetylcholine receptors modulate motivation to self-administer nicotine: Implications for smoking and schizophrenia. Neuropsychopharmacology 37: 1134-1143.

Brunzell DH, Chang JR, Schneider B, Olausson P, Taylor JR, Picciotto MR. 2006. $\beta 2$-Subunit-containing nicotinic acetylcholine receptors are involved in nicotine-induced 
increases in conditioned reinforcement but not progressive ratio responding for food in C57BL/6 mice. Psychopharmacology 184: 328-338.

Brunzell D, Mineur Y, Neve R, Picciotto M. 2009. Nucleus accumbens CREB activity is necessary for nicotine conditioned place preference. Neuropsychopharmacology 34: 1993-2001.

Brunzell D, Boschen K, Hendrick E, Beardsley P, McIntosh J. 2010. $\alpha$-Conotoxin MII-sensitive nicotinic acetylcholine receptors in the nucleus accumbens shell regulate progressive ratio responding maintained by nicotine. Neuropsychopharmacology 35: 665-673.

Caldarone BJ, Harrist A, Cleary MA, Beech RD, King SL, Picciotto MR. 2004. High-affinity nicotinic acetylcholine receptors are required for antidepressant effects of amitriptyline on behavior and hippocampal cell proliferation. Biol Psychiatry 56: 657-664.

Caldarone BJ, King SL, Picciotto MR. 2008. Sex differences in anxiety-like behavior and locomotor activity following chronic nicotine exposure in mice. Neurosci Lett 439: 187-191.

Caldarone B, Wang D, Paterson N, Manzano M, Fedolak A, Cavino K, Kwan M, Hanania T, Chellappan S, Kozikowski A, et al. 2011. Dissociation between duration of action in the forced swim test in mice and nicotinic acetylcholine receptor occupancy with sazetidine, varenicline, and 5-IA85380. Psychopharmacology 217: 199-210.

Clarke PB, Fu DS, Jakubovic A, Fibiger HC. 1988. Evidence that mesolimbic dopaminergic activation underlies the locomotor stimulant action of nicotine in rats. J Pharmacol Exp Ther 246: 701-708.

Corrigall WA, Franklin KB, Coen KM, Clarke PB. 1992. The mesolimbic dopaminergic system is implicated in the reinforcing effects of nicotine. Psychopharmacology 107: 285-289.

Corrigall WA, Coen KM, Adamson KL. 1994. Self-administered nicotine activates the mesolimbic dopamine system through the ventral tegmental area. Brain Res 653: 278 284.

Counotte DS, Goriounova NA, Li KW, Loos M, van der Schors RC, Schetters D, Schoffelmeer ANM, Smit AB, Mansvelder HD, Pattij T, et al. 2011. Lasting synaptic changes underlie attention deficits caused by nicotine exposure during adolescence. Nat Neurosci 14: 417-419.

Cuello AC, Emson PC, Paxinos G, Jessell T. 1978. Substance $\mathrm{P}$ containing and cholinergic projections from the habenula. Brain Res 149: 413-429.

De Biasi M, Salas R. 2008. Influence of neuronal nicotinic receptors over nicotine addiction and withdrawal. Exp Biol Med 233: 917-929.

Doherty K, Kinnunen T, Militello FS, Garvey AJ. 1995. Urges to smoke during the first month of abstinence: Relationship to relapse and predictors. Psychopharmacology 119: $171-178$.

Drenan R, Grady S, Whiteaker P, McClure-Begley T, McKinney S, Miwa J, Bupp S, Heintz N, McIntosh J, Bencherif $\mathrm{M}$, et al. 2008a. In vivo activation of midbrain dopamine neurons via sensitized, high-affinity $\alpha 6^{*}$ nicotinic acetylcholine receptors. Neuron 60: 123-136.

Drenan RM, Nashmi R, Imoukhuede P, Just H, McKinney S, Lester HA. 2008b. Subcellular trafficking, pentameric assembly, and subunit stoichiometry of neuronal nicotinic acetylcholine receptors containing fluorescently labeled $\alpha 6$ and $\beta 3$ subunits. Mol Pharmacol 73: 27-41.

Drenan RM, Grady SR, Steele AD, McKinney S, Patzlaff NE, McIntosh JM, Marks MJ, Miwa JM, Lester HA. 2010. Cholinergic modulation of locomotion and striatal dopamine release is mediated by $\alpha 6 \alpha 4^{*}$ nicotinic acetylcholine receptors. J Neurosci 30: 9877-9889.

Eckenrode TC, Barr GA, Battisti WP, Murray M. 1987. Acetylcholine in the interpeduncular nucleus of the rat: Normal distribution and effects of deafferentation. Brain Res 418: $273-286$.

Exley R, Maubourguet N, David V, Eddine R, Evrard A, Pons S, Marti F, Threlfell S, Cazala P, McIntosh JM, et al. 2011. Distinct contributions of nicotinic acetylcholine receptor subunit $\alpha 4$ and subunit $\alpha 6$ to the reinforcing effects of nicotine. Proc Natl Acad Sci 108: 7577-7582.

File SE, Cheeta S, Kenny PJ. 2000. Neurobiological mechanisms by which nicotine mediates different types of anxiety. Eur J Pharmacol 393: 231-236.

Fowler CD, Lu Q, Johnson PM, Marks MJ, Kenny PJ. 2011. Habenular $\alpha 5$ nicotinic receptor subunit signalling controls nicotine intake. Nature 471: 597-601.

Frahm S, Slimak MA, Ferrarese L, Santos-Torres J, AntolinFontes B, Auer S, Filkin S, Pons S, Fontaine J-F, Tsetlin V, et al. 2011. Aversion to nicotine is regulated by the balanced activity of $\beta 4$ and $\alpha 5$ nicotinic receptor subunits in the medial habenula. Neuron 70: 522-535.

Freedman R, Olincy A, Ross RG, Waldo MC, Stevens KE, Adler LE, Leonard S. 2003. The genetics of sensory gating deficits in schizophrenia. Curr Psychiatry Rep 5: $155-161$.

Gangitano D, Salas R, Teng Y, Perez E, De Biasi M. 2009. Progesterone modulation of $\alpha 5 \mathrm{nAChR}$ subunits influences anxiety-related behavior during estrus cycle. Genes Brain Behav 8: 398-406.

George TP, Vessicchio JC, Termine A, Sahady DM, Head CA, Pepper WT, Kosten TR, Wexler BE. 2002. Effects of smoking abstinence on visuospatial working memory function in schizophrenia. Neuropsychopharmacology 26: 75-85.

George TP, Sacco KA, Vessicchio JC, Weinberger AH, Shytle RD. 2008. Nicotinic antagonist augmentation of selective serotonin reuptake inhibitor-refractory major depressive disorder: A preliminary study. J Clin Psychopharm 28: $340-344$.

Girod R, Barazangi N, McGehee D, Role LW. 2000. Facilitation of glutamatergic neurotransmission by presynaptic nicotinic acetylcholine receptors. Neuropharmacology 39: 2715-2725.

Gotti C, Guiducci S, Tedesco V, Corbioli S, Zanetti L, Moretti M, Zanardi A, Rimondini R, Mugnaini M, Clementi F, et al. 2010. Nicotinic acetylcholine receptors in the mesolimbic pathway: Primary role of ventral tegmental area $\alpha 6 \beta 2^{*}$ receptors in mediating systemic nicotine effects on dopamine release, locomotion, and reinforcement. J Neurosci 30: 5311-5325.

Grady SR, Meinerz NM, Cao J, Reynolds A, Picciotto MR, Changeux J-P, McIntosh MJ, Marks MJ, Collins AC. 2001. Nicotinic agonists stimulate acetylcholine release from mouse interpeduncular nucleus: A function mediated by a different nAChR than dopamine release from striatum. J Neurochem 76: 258-268. 
Grady S, Moretti M, Zoli M, Marks M, Zanardi A, Pucci L, Clementi F, Gotti C. 2009. Rodent habenulo-interpeduncular pathway expresses a large variety of uncommon nAChR subtypes, but only the $\alpha 3 \beta 4^{*}$ and $\alpha 3 \beta 3 \beta 4^{*}$ subtypes mediate acetylcholine release. J Neurosci 29: $2272-$ 2282.

Grucza RA, Wang JC, Stitzel JA, Hinrichs AL, Saccone SF, Saccone NL, Bucholz KK, Cloninger CR, Neuman RJ, Budde JP, et al. 2008. A risk allele for nicotine dependence in CHRNA5 is a protective allele for cocaine dependence. Biol Psychiatry 64: 922-929.

Grunberg NE, Winders SE, Popp KA. 1987. Sex differences in nicotine's effects on consummatory behavior and body weight in rats. Psychopharmacology 91: 221-225.

Hajnal A, Pothos EN, Lenard L, Hoebel BG. 1998. Effects of feeding and insulin on extracellular acetylcholine in the amygdala of freely moving rats. Brain Res 785: 41-48.

Heath CJ, Picciotto MR. 2009. Nicotine-induced plasticity during development: Modulation of the cholinergic system and long-term consequences for circuits involved in attention and sensory processing. Neuropharmacology 56: $254-262$.

Heath CJ, King SL, Gotti C, Marks MJ, Picciotto MR. 2010. Cortico-thalamic connectivity is vulnerable to nicotine exposure during early postnatal development through $\alpha 4 / \beta 2 / \alpha 5$ nicotinic acetylcholine receptors. Neuropsychopharmacology 35: 2324-2338.

Hikosaka O. 2010. The habenula: From stress evasion to value-based decision-making. Nature Rev Neurosci 11: 503-513.

Huang H, Xu Y, van den Pol A. 2011. Nicotine excites hypothalamic arcuate anorexigenic proopiomelanocortin neurons and orexigenic neuropeptide Y neurons: Similarities and differences. J Neurophysiol 106: 1191-1202.

Hung RJ, McKay JD, Gaborieau V, Boffetta P, Hashibe M, Zaridze D, Mukeria A, Szeszenia-Dabrowska N, Lissowska J, Rudnai P, et al. 2008. A susceptibility locus for lung cancer maps to nicotinic acetylcholine receptor subunit genes on 15q25. Nature 452: 633-637.

Jhou TC, Fields HL, Baxter MG, Saper CB, Holland PC. 2009. The rostromedial tegmental nucleus (RMTg), a GABAergic afferent to midbrain dopamine neurons, encodes aversive stimuli and inhibits motor responses. $\mathrm{Neu}$ ron 61: 786-800.

Jo YH, Talmage DA, Role LW. 2002. Nicotinic receptor-mediated effects on appetite and food intake. J Neurobiology 53: 618-632.

Jo Y-H, Wiedl D, Role LW. 2005. Cholinergic modulation of appetite-related synapses in mouse lateral hypothalamic slice. J Neurosci 25: 11133-11144.

Kalman D, Morissette S, George T. 2005. Co-morbidity of smoking in patients with psychiatric and substance use disorders. Am J Addictions 14: 106-123.

Kassam S, Herman P, Goodfellow N, Alves N, Lambe E. 2008. Developmental excitation of corticothalamic neurons by nicotinic acetylcholine receptors. J Neurosci 28: 8756-8764.

Kenny PJ. 2011. Common cellular and molecular mechanisms in obesity and drug addiction. Nat Rev Neurosci 12: $638-651$.
Kenny PJ, Markou A. 2001. Neurobiology of the nicotine withdrawal syndrome. Pharmacol Biochem Behav 70: 531-549.

King SL, Marks MJ, Grady SR, Caldarone BJ, Koren AO, Mukhin AG, Collins AC, Picciotto MR. 2003. Conditional expression in corticothalamic efferents reveals a developmental role for nicotinic acetylcholine receptors in modulation of passive avoidance behavior. J Neurosci 23: 3837-3843.

King S, Caldarone B, Picciotto M. 2004. $\beta 2$-Subunit-containing nicotinic acetylcholine receptors are critical for dopamine-dependent locomotor activation following repeated nicotine administration. Neuropharmacology 47: $132-139$.

Klink R, de Kerchove d'Exaerde A, Zoli M, Changeux JP. 2001. Molecular and physiological diversity of nicotinic acetylcholine receptors in the midbrain dopaminergic nuclei. J Neurosci 21: 1452-1463.

Koob GF. 1992. Drugs of abuse: Anatomy, pharmacology and function of reward pathways. Trends Pharmacol Sci 13: $177-184$.

Lambe EK, Olausson P, Horst NK, Taylor JR, Aghajanian GK. 2005. Hypocretin and nicotine excite the same thalamocortical synapses in prefrontal cortex: Correlation with improved attention in rat. J Neurosci 25: 5225-5229.

Lasser K, Boyd JW, Woolhandler S, Himmelstein DU, McCormick D, Bor DH. 2000. Smoking and mental illness: A population-based prevalence study. JAMA 284: 26062610.

Lecourtier L, Kelly PH. 2007. A conductor hidden in the orchestra? Role of the habenular complex in monoamine transmission and cognition. Neurosci Biobehav Rev 31: 658-672.

Le Marchand L, Derby KS, Murphy SE, Hecht SS, Hatsukami D, Carmella SG, Tiirikainen M, Wang H. 2008. Smokers with the CHRNA lung cancer-associated variants are exposed to higher levels of nicotine equivalents and a carcinogenic tobacco-specific nitrosamine. Cancer Res 68: 9137-9140.

Le Novère N, Zoli M, Changeux J-P. 1996. Neuronal nicotinic receptor $\alpha 6$ subunit mRNA is selectively concentrated in catecholaminergic nuclei of the rat brain. Eur $J$ Neurosci 8: 2428-2439.

Leonard S, Breese C, Adams C, Benhammou K, Gault J, Stevens K, Lee M, Adler L, Olincy A, Ross R, et al. 2000. Smoking and schizophrenia: Abnormal nicotinic receptor expression. Eur J Pharmacol 393: 237-242.

Lips EH, Gaborieau V, McKay JD, Chabrier A, Hung RJ, Boffetta P, Hashibe M, Zaridze D, Szeszenia-Dabrowska N, Lissowska J, et al. 2010. Association between a 15q25 gene variant, smoking quantity and tobacco-related cancers among 17,000 individuals. Int J Epidemiol 39: $563-$ 577.

Mansvelder HD, McGehee DS. 2000. Long-term potentiation of excitatory inputs to brain reward areas by nicotine. Neuron 27: 349-357.

Mansvelder HD, Keath JR, McGehee DS. 2002. Synaptic mechanisms underlie nicotine-induced excitability of brain reward areas. Neuron 33: 905-919.

Maskos U, Molles BE, Pons S, Besson M, Guiard BP, Guilloux JP, Evrard A, Cazala P, Cormier A, Mameli-Engvall $\mathrm{M}$, et al. 2005. Nicotine reinforcement and cognition 
restored by targeted expression of nicotinic receptors. Nature 436: 103-107.

Mata MM, Schrier BK, Moore RY. 1977. Interpeduncular nucleus: Differential effects of habenula lesions on choline acetyltransferase and glutamic acid decarboxylase. Exp Neurol 57: 913-921.

Matsumoto M, Hikosaka O. 2009. Representation of negative motivational value in the primate lateral habenula Nature Neurosci 12: 77-84.

McGranahan TM, Patzlaff NE, Grady SR, Heinemann SF, Booker TK. 2011. $\alpha 4 \beta 2$ nicotinic acetylcholine receptors on dopaminergic neurons mediate nicotine reward and anxiety relief. J Neurosci 31: 10891-10902.

Mineur YS, Somenzi O, Picciotto MR. 2007. Cytisine, a partial agonist of high-affinity nicotinic acetylcholine receptors, has antidepressant-like properties in male C57BL/6J mice. Neuropharmacology 52: 1256-1262.

Mineur Y, Brunzell D, Grady S, Lindstrom J, McIntosh J, Marks M, King S, Picciotto M. 2009a. Localized low level re-expression of high affinity mesolimbic nicotinic acetylcholine receptors restores nicotine-induced locomotion but not place conditioning. Genes Brain Behav 8: 257-266.

Mineur YS, Eibl C, Young G, Kochevar C, Papke RL, Gundisch D, Picciotto MR. 2009b. Cytisine-based nicotinic partial agonists as novel antidepressant compounds. J Pharmacol Exp Therap 329: 377-386.

Mineur YS, Abizaid A, Rao Y, Salas R, DiLeone RJ, Gundisch D, Diano S, De Biasi M, Horvath TL, Gao X-B, et al. 2011a. Nicotine decreases food intake through activation of POMC neurons. Science 332: 1330-1332.

Mineur YS, Einstein EB, Seymour PA, Coe JW, O'Neill BT, Rollema H, Picciotto MR. 2011b. $\alpha 4 \beta 2$ nicotinic acetylcholine receptor partial agonists with low intrinsic efficacy have antidepressant-like properties. Behav Pharmacol 22: 291-299.

Morishita H, Miwa JM, Heintz N, Hensch TK. 2010. Lynx1, a cholinergic brake, limits plasticity in adult visual cortex. Science 330: $1238-1240$

Mugnaini M, Tessari M, Tarter G, Merlo Pich E, Chiamulera C, Bunnemann B. 2002. Upregulation of [3H]methyllycaconitine binding sites following continuous infusion of nicotine, without changes of $\alpha 7$ or $\alpha 6$ subunit mRNA: An autoradiography and in situ hybridization study in rat brain. Euro J Neurosci 16: 1633-1646.

Museo E, Wise RA. 1994. Place preference conditioning with ventral tegmental injections of cytisine. Life Sci 55: 1179 1186.

Parikh V, Kozak R, Martinez V, Sarter M, Parikh V, Kozak R, Martinez V, Sarter M. 2007. Prefrontal acetylcholine release controls cue detection on multiple timescales. $\mathrm{Neu}$ ron 56: $141-154$.

Parikh V, Man K, Decker MW, Sarter M, Parikh V, Man K, Decker MW, Sarter M. 2008. Glutamatergic contributions to nicotinic acetylcholine receptor agonist-evoked cholinergic transients in the prefrontal cortex. J Neurosci 28: $3769-3780$.

Parrott AC. 1993. Cigarette smoking: Effects upon self-rated stress and arousal over the day. Addictive Behav 18: 389395.
Philip NS, Carpenter LL, Tyrka AR, Whiteley LB, Price LH 2009. Varenicline augmentation in depressed smokers: An 8-week, open-label study. J Clin Psychiatry 70: 1026-1031.

Piasecki TM, Fiore MC, Baker TB. 1998. Profiles in discouragement: Two studies of variability in the time course of smoking withdrawal symptoms. J Abnorm Psychol 107: 238-251.

Piasecki TM, Niaura R, Shadel WG, Abrams D, Goldstein M, Fiore MC, Baker TB. 2000. Smoking withdrawal dynamics in unaided quitters. J Abnorm Psychol 109: 74-86.

Piasecki TM, Jorenby DE, Smith SS, Fiore MC, Baker TB. 2003. Smoking withdrawal dynamics: II. Improved tests of withdrawal-relapse relations. J Abnorm Psychol 112: $14-27$.

Picciotto MR. 2003. Nicotine as a modulator of behavior: Beyond the inverted U. Trends Pharmacol Sci 24: $493-$ 499.

Picciotto MR, Zoli M, Léna C, Bessis A, Lallemand Y, Le Novère N, Vincent P, Merlo Pich E, Brulet P, Changeux JP. 1995. Abnormal avoidance learning in mice lacking functional high-affinity nicotine receptor in the brain. Nature 374: 65-67.

Picciotto MR, Zoli M, Rimondini R, Léna C, Marubio LM, Merlo Pich E, Fuxe K, Changeux JP. 1998. Acetylcholine receptors containing the $\beta-2$ subunit are involved in the reinforcing properties of nicotine. Nature 391: 173-177.

Picciotto MR, Brunzell DH, Caldarone BJ. 2002. Effect of nicotine and nicotinic receptors on anxiety and depression. Neuroreport 13: 1097-1106.

Pons S, Fattore L, Cossu G, Tolu S, Porcu E, McIntosh J, Changeux J, Maskos U, Fratta W. 2008. Crucial role of $\alpha 4$ and $\alpha 6$ nicotinic acetylcholine receptor subunits from ventral tegmental area in systemic nicotine self-administration. J Neurosci 28: 12318-12327.

Rabenstein RL, Caldarone BJ, Picciotto MR. 2006. The nicotinic antagonist mecamylamine has antidepressant-like effects in wild type but not $\beta 2$ or $\alpha 7$ nicotinic acetylcholine receptor knockout mice. Psychopharmacology 189: 395-401.

Rada PV, Mark GP, Yeomans JJ, Hoebel BG. 2000. Acetylcholine release in ventral tegmental area by hypothalamic self-stimulation, eating, and drinking. Pharmacol Biochem Behav 65: 375-379.

Ren J, Qin C, Hu F, Tan J, Qiu L, Zhao S, Feng G, Luo M. 2011. Habenula "cholinergic" neurons co-release glutamate and acetylcholine and activate postsynaptic neurons via distinct transmission modes. Neuron 69: 445-452.

Rollema H, Guanowsky V, Mineur Y, Shrikhande A, Coe J, Seymour P, Picciotto M. 2009. Varenicline has antidepressant-like activity in the forced swim test and augments sertraline's effect. Eur J Pharmacol 605: 114-116.

Rusted JM, Warburton DM. 1992. Facilitation of memory by post-trial administration of nicotine: Evidence for an attentional explanation. Psychopharmacology 108: 452455.

Sacco KA, Bannon KL, George TP. 2004. Nicotinic receptor mechanisms and cognition in normal states and neuropsychiatric disorders. J Psychopharmacology 18: 457-474.

Saccone SF, Hinrichs AL, Saccone NL, Chase GA, Konvicka K, Madden PAF, Breslau N, Johnson EO, Hatsukami D, 
M.R. Picciotto and P.J. Kenny

Pomerleau O, et al. 2007. Cholinergic nicotinic receptor genes implicated in a nicotine dependence association study targeting 348 candidate genes with 3713 SNPs. Hum Mol Genetics 16: 36-49.

Saccone NL, Saccone SF, Hinrichs AL, Stitzel JA, Duan W, Pergadia ML, Agrawal A, Breslau N, Grucza RA, Hatsukami D, et al. 2009. Multiple distinct risk loci for nicotine dependence identified by dense coverage of the complete family of nicotinic receptor subunit (CHRN) genes. Am J Med Genet B 150B: 453-466.

Salas R, Pieri F, Fung B, Dani JA, De Biasi M. 2003. Altered anxiety-related responses in mutant mice lacking the $\beta 4$ subunit of the nicotinic receptor. J Neurosci 23: 62556263.

Salas R, Sturm R, Boulter J, De Biasi M. 2009. Nicotinic receptors in the habenulo-interpeduncular system are necessary for nicotine withdrawal in mice. $J$ Neurosci 29: 3014-3018.

Schilstrom B, Svensson HM, Svensson TH, Nomikos GG. 1998. Nicotine and food induced dopamine release in the nucleus accumbens of the rat: Putative role of $\alpha 7$ nicotinic receptors in the ventral tegmental area. Neurosci 85: 1005-1009.

Schlaepfer IR, Hoft NR, Collins AC, Corley RP, Hewitt JK, Hopfer CJ, Lessem JM, McQueen MB, Rhee SH, Ehringer MA. 2008. The CHRNA5/A3/B4 gene cluster variability as an important determinant of early alcohol and tobacco initiation in young adults. Biol Psychiatry 63: 1039-1046.

Sheffield EB, Quick MW, Lester RA. 2000. Nicotinic acetylcholine receptor subunit mRNA expression and channel function in medial habenula neurons. Neuropharmacology 39: 2591-2603.

Sherva R, Wilhelmsen K, Pomerleau CS, Chasse SA, Rice JP, Snedecor SM, Bierut LJ, Neuman RJ, Pomerleau OF. 2008. Association of a single nucleotide polymorphism in neuronal acetylcholine receptor subunit $\alpha 5$ (CHRNA5) with smoking status and with "pleasurable buzz" during early experimentation with smoking. Addiction 103: $1544-1552$.

Stevens VL, Bierut LJ, Talbot JT, Wang JC, Sun J, Hinrichs AL, Thun MJ, Goate A, Calle EE. 2008. Nicotinic receptor gene variants influence susceptibility to heavy smoking. Cancer Epidemiol Biomarkers Prev 17: 3517-3525.

Sugama S, Cho BP, Baker H, Joh TH, Lucero J, Conti B. 2002. Neurons of the superior nucleus of the medial habenula and ependymal cells express IL-18 in rat CNS. Brain Res 958: $1-9$.

Tapper AR, McKinney SL, Nashmi R, Schwarz J, Deshpande P, Labarca C, Whiteaker P, Marks MJ, Collins AC, Lester HA. 2004. Nicotine activation of $\alpha 4^{*}$ receptors: Sufficient for reward, tolerance, and sensitization. Science 306: 1029-1032.

Thorgeirsson TE, Geller F, Sulem P, Rafnar T, Wiste A, Magnusson KP, Manolescu A, Thorleifsson G, Stefansson H, Ingason A, et al. 2008. A variant associated with nicotine dependence, lung cancer and peripheral arterial disease. Nature 452: 638-642.

Tizabi Y, Rezvani AH, Russell LT, Tyler KY, Overstreet DH. 2000. Depressive characteristics of FSL rats: Involvement of central nicotinic receptors. Pharmacol Biochem Behav 66: $73-77$.

Vincent SR, Staines WA, McGeer EG, Fibiger HC. 1980. Transmitters contained in the efferents of the habenula. Brain Res 195: 479-484.

Voorhees CC, Schreiber GB, Schumann BC, Biro F, Crawford PB. 2002. Early predictors of daily smoking in young women: The national heart, lung, and blood institute growth and health study. Prevent Med 34: 616-624.

Walters C, Brown S, Changeux J-P, Martin B, Damaj M. 2006. The $\beta 2$ but not $\alpha 7$ subunit of the nicotinic acetylcholine receptor is required for nicotine-conditioned place preference in mice. Psychopharmacol 184: 339-344.

Wang JC, Cruchaga C, Saccone NL, Bertelsen S, Liu P, Budde JP, Duan W, Fox L, Grucza RA, Kern J, et al. 2009. Risk for nicotine dependence and lung cancer is conferred by mRNA expression levels and amino acid change in CHRNA5. Hum Mol Genetics 18: 3125-3135.

Wang Y, Broderick P, Matakidou A, Eisen T, Houlston RS. 2010. Role of 5p15.33 (TERT-CLPTM1L), 6p21.33 and 15q25.1 (CHRNA5-CHRNA3) variation and lung cancer risk in never-smokers. Carcinogenesis 31: 234-238.

Warburton DM, Rusted JM, Fowler J. 1992. A comparison of the attentional and consolidation hypotheses for the facilitation of memory by nicotine. Psychopharmacology 108: $443-447$.

Weiss RB, Baker TB, Cannon DS, von Niederhausern A, Dunn DM, Matsunami N, Singh NA, Baird L, Coon H, McMahon WM, et al. 2008. A candidate gene approach identifies the CHRNA5-A3-B4 region as a risk factor for age-dependent nicotine addiction. PLoS Genet 4: e1000125.

Wooltorton JRA, Pidoplichko VI, Broide RS, Dani JA. 2003. Differential desensitization and distribution of nicotinic acetylcholine receptor subtypes in midbrain dopamine areas. J Neurosci 23: 3176-3185.

Yang K, Buhlman L, Khan GM, Nichols RA, Jin G, McIntosh JM, Whiteaker P, Lukas RJ, Wu J. 2011. Functional nicotinic acetylcholine receptors containing $\alpha 6$ subunits are on GABAergic neuronal boutons adherent to ventral tegmental area dopamine neurons. J Neurosci 31: 25372548.

Zhou FM, Liang Y, Dani JA. 2001. Endogenous nicotinic cholinergic activity regulates dopamine release in the striatum. Nat. Neurosci 4: 1224-1229.

Zoli M, Moretti M, Zanardi A, McIntosh JM, Clementi F, Gotti C. 2002. Identification of the nicotinic receptor subtypes expressed on dopaminergic terminals in the rat striatum. J Neurosci 22: 8785-8789. 


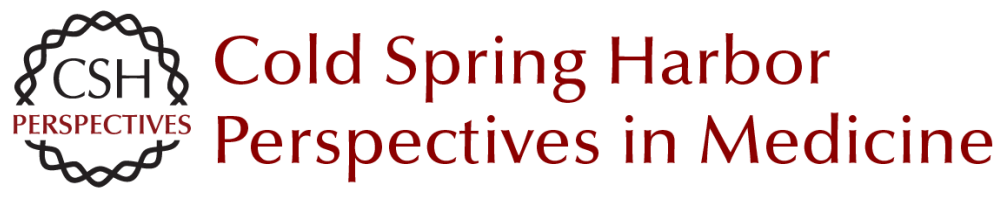

\title{
Molecular Mechanisms Underlying Behaviors Related to Nicotine Addiction
}

\author{
Marina R. Picciotto and Paul J. Kenny
}

Cold Spring Harb Perspect Med 2013; doi: 10.1101/cshperspect.a012112 originally published online November 9, 2012

\section{Subject Collection Addiction}

Developments from Bulk Optogenetics to

Single-Cell Strategies to Dissect the Neural

Circuits that Underlie Aberrant Motivational States Jose Rodriguez-Romaguera, Vijay M.K. Namboodiri, Marcus L. Basiri, et al.

Consequences of Parental Opioid Exposure on Neurophysiology, Behavior, and Health in the Next Generations

Fair M. Vassoler and Mathieu E. Wimmer

Animal Models of the Behavioral Symptoms of Substance Use Disorders Louk J.M.J. Vanderschuren and Serge H. Ahmed

Translational Research in Nicotine Addiction Miranda L. Fisher, James R. Pauly, Brett Froeliger, et al.

Neonatal Opioid Withdrawal Syndrome (NOWS): A Transgenerational Echo of the Opioid Crisis Andrew E. Weller, Richard C. Crist, Benjamin C. Reiner, et al.

Impairment of Synaptic Plasticity by Cannabis, $\Delta^{\mathbf{9}}$ -THC, and Synthetic Cannabinoids Alexander F. Hoffman, Eun-Kyung Hwang and Carl R. Lupica

Drug-Evoked Synaptic Plasticity of Excitatory Transmission in the Ventral Tegmental Area Camilla Bellone, Michael Loureiro and Christian Lüscher

Opioid-Induced Molecular and Cellular Plasticity of Ventral Tegmental Area Dopamine Neurons Marie A. Doyle and Michelle S. Mazei-Robison
The Persistent Challenge of Developing Addiction

Pharmacotherapies

Sarah E. Swinford-Jackson, Charles P. O'Brien,

Paul J. Kenny, et al.

Opioid Modulation of the Gut-Brain Axis in Opioid-Associated Comorbidities

Li Zhang and Sabita Roy

Epigenetics of Drug Addiction Andrew F. Stewart, Sasha L. Fulton and lan Maze

Genetic Vulnerability to Opioid Addiction Brian Reed and Mary Jeanne Kreek

Glutamatergic Systems and Memory Mechanisms Underlying Opioid Addiction Jasper A. Heinsbroek, Taco J. De Vries and Jamie Peters

Mechanisms of Nicotine Addiction Marina R. Picciotto and Paul J. Kenny

Neural Substrates and Circuits of Drug Addiction Matthew W. Feltenstein, Ronald E. See and Rita A. Fuchs

The Role of the Central Amygdala in Alcohol Dependence Marisa Roberto, Dean Kirson and Sophia Khom

For additional articles in this collection, see http://perspectivesinmedicine.cshlp.org/cgi/collection/ 